\title{
Ecological Compensation: A Key to Sustainable Development in the Guizhou Province Karst Region, Southwest China
}

\author{
Chuanyan Zhou 1,2,3, Brita M. Svensson ${ }^{2 *}$, Junhua Yan ${ }^{4}$, Xun Chen ${ }^{5}$, Kun Li ${ }^{4}$ \\ ${ }^{1}$ College of Environment and Energy, South China University of Technology, Guangzhou, China \\ ${ }^{2}$ Department of Plant Ecology and Evolution, Uppsala University, Uppsala, Sweden \\ ${ }^{3}$ Guizhou Mountain Resources Institute, Guiyang, China \\ ${ }^{4}$ South China Botanical Garden, Chinese Academy of Sciences, Guangzhou, China \\ ${ }^{5}$ Guizhou Academy of Sciences, Guiyang, China \\ Email: ${ }^{*}$ brita.svensson@ebc.uu.se
}

Received 13 December 2013; revised 2 February 2014; accepted 26 February 2014

Copyright (C) 2014 by authors and Scientific Research Publishing Inc.

This work is licensed under the Creative Commons Attribution International License (CC BY).

http://creativecommons.org/licenses/by/4.0/

(c) (i) Open Access

\section{Abstract}

The conflict between poverty and the resulting over-exploitation of natural resources on the one hand, and ecological restoration and sustainable development on the other hand, in the southwest China karst region was studied. In this region, the karst forest (a mixed evergreen and deciduous broad-leaved forest) is rapidly degrading due to over-exploitation (sloping farming). We suggest that an Ecological Compensation (EC) model should be established with: financial institutions, local people, and a third part as an intermediate link. The process would continue for 20 years. As a case study we used Bangui town (3800 families) in the upper reaches of Pearl River. The per capita income of residents was used as the benchmark. The compensation would start with $80 \%$, and decrease to $20 \%$ over a period of 20 years. Infrastructure investment would decrease from $20 \%$ of the total person's compensation to $5 \%$ as the farmers increasingly use alternative income sources. The EC includes compensation for individual, infrastructure, and environmental investments. The total $\mathrm{EC}$ for Bangui would be $305,064 \times 10^{4}$ yuan during the 20 years.

\section{Keywords}

Bangui Town, Ecosystem Service, Karst Forest, Net Primary Production, Opportunity Cost, Rocky Desertification, Sloping Farming

\footnotetext{
${ }^{*}$ Corresponding author.
}

How to cite this paper: Zhou, C. Y., et al. (2014). Ecological Compensation: A Key to Sustainable Development in the Guizhou Province Karst Region, Southwest China. Open Journal of Forestry, 4, 212-222. 


\section{Introduction}

Ecological degradation and poverty are the two most significant problems in the karst region of southwest China. It is estimated that karst geomorphology covers about $620,000 \mathrm{~km}^{2}$ in this region, involving the provinces Sichuan, Hunan, Hubei, Guangdong, Guizhou, Yunnan, and Chongqing municipality, and the Guangxi Zhuang autonomous region (Huang et al., 2008). The total area of soil erosion in Yunnan, Guizhou and Guangxi Zhuang has reached $179,600 \mathrm{~km}^{2}$, affecting about $40 \%$ of the total land area (Wang et al., 2004). According to the criteria set up by the State Council of the PR China, 48 of Guizhou's 77 counties are currently in poverty. The population living in poverty totals 9.1 million, which is nearly a quarter of the population of the province and is oneseventh of the total poverty population of China (Huang et al., 2008). One of the reasons behind this high incidence of poverty is the over-exploitation of natural resources (Zhang et al., 2001), a problem also significant in other parts of the world, e.g., Bangladesh (Jashimuddin \& Inoue, 2012), Brazil (Sawakuchi et al., 2013), and Burkina Faso (Thiombiano et al., 2013). Therefore, much research on ecological degradation and restoration of this region has been done in the last 30 years. For example, in one case shrub vegetation was restored and formed by Itea ilicifolia Oliv. and Platycarya strobilacea Sieb. et Zucc. after stopping human disturbance for twenty years in Guiyang's Eleven Cave area (Huang et al., 1988).

There are still forests worth protecting around the villages in the karst region but it has become increasingly common to exploit these for sloping farming in order to increase grain harvest. Peng et al. (2008) have shown that unreasonable land use is one of the main reasons behind the speeding ecological degradation; the result being rocky desertification, while at the same time the people living here could not escape from poverty. To achieve ecological restoration, the farmers need to give up sloping farming to reduce soil erosion and restore the natural vegetation, i.e., the karst forest. However, this is not an easy task. The livelihood of the farmers depends on profits from farm-related economic activities for many generations. Banning sloping farming and other economic activities will exacerbate hardship for the farmers, and create and intensify conflicts between the government and farmers. How to manage natural resources without significant detrimental effects on the environment becomes the most important issue in the karst region if we are to save the forest ecosystem.

To achieve a sustainable development in the karst region of Southwest China and to get away from the "poverty trap” (Cai, 2006; Cao et al., 2009) should not be an issue for discussion only. Instead we need to act. In this paper we try to demonstrate that it is time for a special Ecological Compensation (EC) model to be implemented in this area. We chose a site in Guizhou province as a case study in the hope that similar schemes can be implemented also in other areas, when needed.

Ecological compensation (EC) is not only an effective guarantee for each region to obtain equal rights of survival, development as well as a decent environment, but also an essential assurance to a coordinated, balanced, and sustainable development among various regions (Zhang et al., 2010). EC is the key instrument to alleviate poverty while at the same time conserving the environment (Wan et al., 2005). It was realized that EC in China has a political, social, economic, and legal basis (Peng et al., 2008). To this point, EC has been widely carried out at different scales. For example, the Chinese government has been implementing the Natural Forest Protection Project (NFPP) from 1998 and the Sloping Land Conversion Project (SLCP) from 2002 (Wan et al., 2005). In an EC program the government plays the role of payer and facilitator. Obviously, people would not approve to pay for resources that used to be free, such as what the forests have been providing. Strengthening and sustaining EC is, therefore, a way for local farmers to use ecosystem services without destroying the environment that provides them.

However, how to achieve a reasonable compensation in the karst region is an important issue and the focus of this paper. From our six-year long research on ecological restoration, we found that achieving sustainable development here is to a great extent an issue of policy. In any country there is a balance of interests and the Chinese Central Government has recognized this problem. Ecological compensation in the karst region was put forward in Decree No. 2, the State Council of the People's Republic of China in 2012. To implement an Ecological Compensation model, as a pilot project, in part of the upper reaches of the Pearl River was articulated in this document. Therefore, we have built this framework of an EC for the karst region. In fact, one of the objectives of this paper is to develop a model for managing an EC in a sustainable and environmentally friendly manner. This model should provide a basis for policy-making for the Chinese government.

The local farmers of the Guizhou karst region are in need for a special EC program for the following three reasons: 1) outputs from farming the sloping fields are limited while at the same time leading to forest degrada- 
tion with strong soil erosion and eventually rocky desertification; 2) farming of sloping fields needs to be replaced by another kind of farming; and 3) local poverty could be eliminated and ecosystem services improved at the same time. The main purpose of our study is to answer the following four questions:

1) How will Net Primary Productivity (NPP) of sloping land be affected if the vegetation is changed from sloping fields to forest?

2) How will the total value of ecosystem services change after implementing EC in the karst region?

3) What is the farmers' opportunity cost if they have to stop sloping farming?

4) Which is the best method to determine the appropriate EC for karst forest regions?

\section{Methods}

\subsection{Study Area}

Guizhou province $\left(103^{\circ} 36^{\prime}-109^{\circ} 35^{\prime} \mathrm{E}, 24^{\circ} 37^{\prime}-29^{\circ} 13^{\prime} \mathrm{N}\right)$ in southwest China (Figure 1) is located in the middle of the East Asia karst area which is the most complex and largest karst formation of the world (Wan, 2003). The total area of the Guizhou province is $176,128 \mathrm{~km}^{2}$ and $62 \%$ of this is karst. Annual precipitation is $1000-1500$ $\mathrm{mm}$ and average annual temperature is $10^{\circ} \mathrm{C}-18^{\circ} \mathrm{C}$. The average annual sunshine hours are $1300 \mathrm{~h}$ and the frostfree period is about $270 \mathrm{~d}$ per year (Tian et al., 2011). Remote sensing reveals that karst rocky desertification land covers $35,000 \mathrm{~km}^{2}$, which is about $20 \%$ of the area of the province (Wang et al., 2004).

Bangui town was used as a case study. Bangui is located in the Beipanjiang basin in the upper reaches of the Pearl River (Figure 2). The total area of Bangui is more than $137 \mathrm{~km}^{2}, 3800$ families live here and the total population is 19,000 . The annual average temperature is $19^{\circ}$ and annual precipitation is $1000 \mathrm{~mm}$. Altitude is between 370 and $1355 \mathrm{~m}$, a typical karst canyon and the frost-free period is about 339 days per year.

\subsection{Net Primary Productivity and Biological Productivity}

In this paper we will sum up and evaluate the NPP of different land use in the karst region of the Guizhou province. Yang and Chen (1991) studied the biomass of the karst forest community in Maolan located in the south of Guizhou province, a mixed evergreen and deciduous broad-leaved forest, which is the climax community in karst areas. The forest has a total biomass of about $146-191 \mathrm{t} / \mathrm{hm}^{2}$ (Yang \& Chen, 1991). Compared with the existing types of forests in the world, it is a low biomass forest. Therefore low biological productivity is an important characteristic in this karst region.

\subsection{Ecosystem Service Value}

Costanza et al. (1997) suggested 17 kinds of ecosystem services and functions. Xie et al. (2003) applied Co-

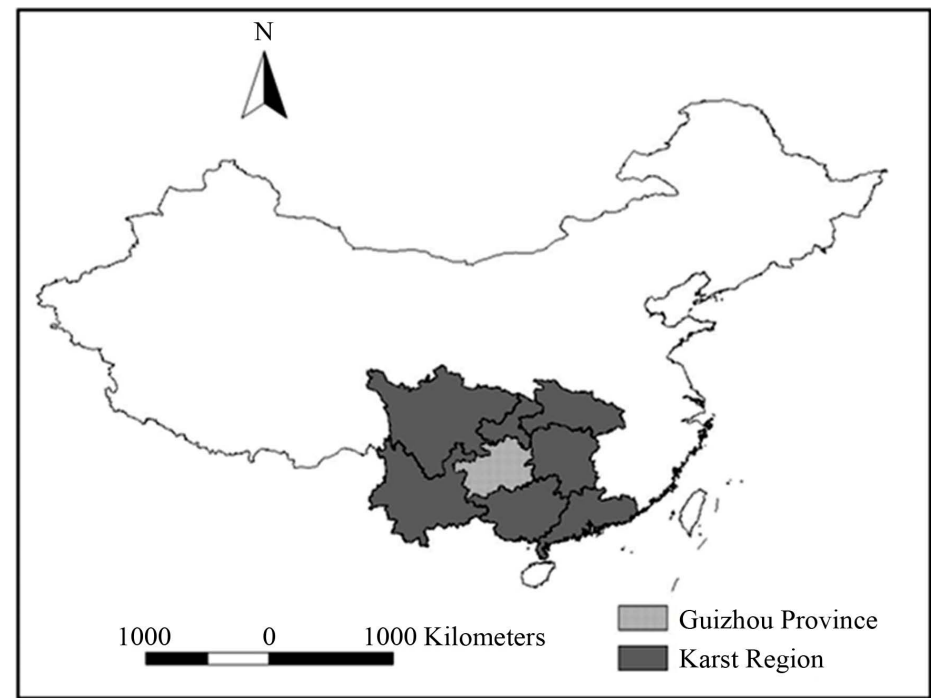

Figure 1. The location of Guizhou province in the middle of the karst area. 


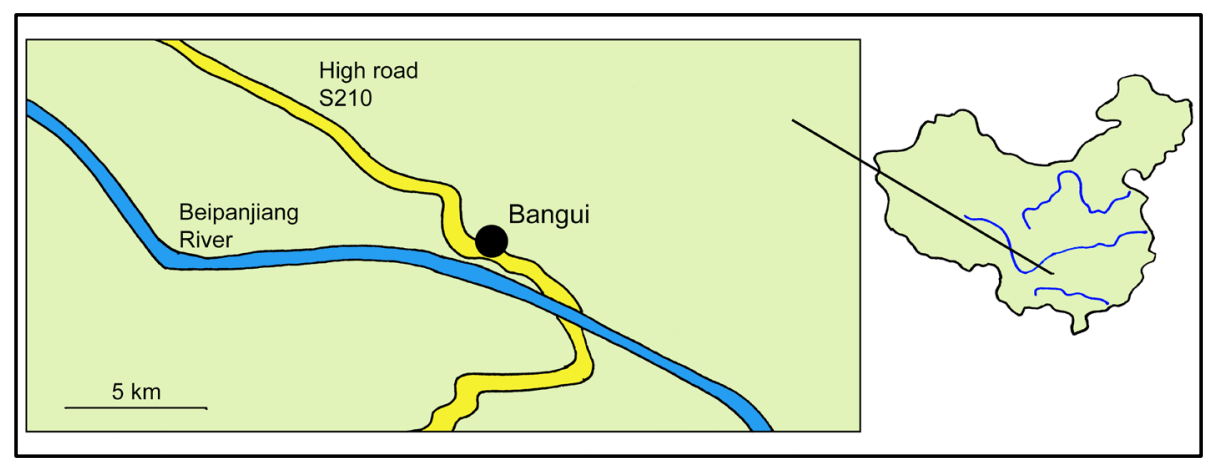

Figure 2. The geographic location of Bangui town village in SE China.

stanza's method and evaluated the ecosystem service value per unit area of China's terrestrial ecosystems. They determined nine kinds of ecosystem services; listed in Table 1. Xie et al. $(2003,2006)$ set the value for farm and ecosystem services to 1 for every $\mathrm{hm}^{2}$. This economic value of 1 is equal to one seventh of the average grain yield market value. Xiao et al. (2003) studied the economic value of ecosystem services in Mangcuo lake drainage basin also using Xie et al.'s method. They adapted Equation (1) to evaluate the economic value of every equivalent of ecosystem services (Xiao et al., 2003; Xie et al., 2003, 2006) as:

$$
E_{a}=1 / 7 \sum_{i=1}^{n} \frac{m_{i} p_{i} q_{i}}{M}(i=1, \cdots, n)
$$

where $E_{a}$ is the economic value of every equivalent of ecosystem services to $1 \mathrm{hm}^{2}$; " $p$ " is the average price in China of crop " $i$ " (yuan $\left.t^{-1}\right)$; " $q_{i}$ ” is per unit area yield of crop " $i$ " $\left(\mathrm{t} \cdot \mathrm{hm} \mathrm{m}^{-2}\right)$; " $m_{i}$ ” is the area of crop " $i$ " $\left(\mathrm{hm}^{2}\right)$; and $M$ is the total area of all types of crops $\left(\mathrm{hm}^{2}\right)$. The main crops in the Guizhou province are rice (Oryza sativa L.), maize (Zea mays L. ssp. mays), and rapeseed (Brassica napus L.).

Using $E_{a}$ and the relationship between $E_{a}$ and other ecosystem services, we can evaluate the unit price of other types of ecosystem services or ecosystems by using Equation (2):

$$
E_{i j}=e_{i j} E_{a}(i=1,2, \cdots, 9 ; j=1,2, \cdots, 6)
$$

where $E_{i j}$ is the ecosystem service unit price of " $i$ ” in ecosystem “ $j$ ” (yuan $\cdot \mathrm{hm}^{-2}$ ); $e_{i j}$ is the equivalency factor of " $i$ " in ecosystem " $j$ "; " $i$ " is one of the nine ecosystem services; and " $j$ " is one of the six ecosystem types.

The total economic value $(V)$ of ecosystems becomes:

$$
V=\sum_{i=0}^{9} \sum_{j=1}^{6} A_{j} E_{i j}(i=1, \cdots, 9 ; j=1, \cdots, 6)
$$

where $A_{j}$ is the area of ecosystem " $j$ ”.

\subsection{Opportunity Cost}

Farmers in the Guizhou karst region almost exclusively plant maize on sloping land (Zhou pers. obs.). We, therefore, used the average yield and market price of maize to evaluate the income difference between implementing SLCP or not, using Equations (4) and (5). At the same time we could calculate the opportunity cost of stopping sloping farming. We adopted the data of the year 2005.

$$
\begin{gathered}
I_{S}=Y\left(A_{T}-A_{S}\right) P_{M}+S A_{S} P_{S} \\
I=Y A_{T} P_{M}
\end{gathered}
$$

where " $I_{S}$ " is the average income of implementing SLCP; " $Y$ " is the average yield of maize; " $A_{T}$ " is the average farmland area per capita; " $A_{S}$ " is the average area per capita which is under the implementing of SLCP; " $P_{M}$ " is market price of maize; " $P_{S}$ " is the price which was determined by SLCP; and " $I$ " is the average income if SLCP were not implemented. 
Table 1. Ecosystem service value per unit area in six of China’s terrestrial ecosystems (the service value for food provision is set to 1).

\begin{tabular}{ccccccc}
\hline Ecosystem & Farmland & Forest & Grassland & Wetland & Water body & Desert \\
Gas regulation & 0.50 & 3.50 & 0.80 & 1.80 & 0.00 & 0.00 \\
Climate regulation & 0.89 & 2.70 & 0.90 & 17.1 & 0.46 & 0.00 \\
Water conservation & 0.60 & 3.20 & 0.80 & 15.5 & 20.4 & 0.03 \\
Soil conservation & 1.46 & 3.90 & 1.95 & 1.71 & 0.01 & 0.02 \\
Waste disposal & 1.64 & 1.31 & 1.31 & 18.2 & 18.2 & 0.01 \\
Biodiversity & 0.71 & 3.26 & 1.09 & 2.50 & 2.49 & 0.34 \\
Food provision & 1.00 & 0.10 & 0.30 & 0.30 & 0.10 & 0.01 \\
Raw material & 0.10 & 2.60 & 0.05 & 0.07 & 0.01 & 0.00 \\
Entertainment & 0.01 & 1.28 & 0.04 & 5.55 & 4.34 & 0.01 \\
Total & 6.91 & 19.7 & 7.24 & 62.7 & 46.0 & 0.42 \\
\hline
\end{tabular}

\section{Results}

\subsection{Changes in the Vegetation's NPP after Stopping Sloping Cultivating}

After about 35 years of prohibition of human disturbance, the shrub-herb land will have gone through different successional stages and returned to karst forest (Huang et al., 1988). We also observed that after 20 months of fallow the sloping fields will be covered with shrubs and herbs. It takes about 37 years for the sloping fields to become forest naturally after farming has ceased (Huang et al., 1988). The succession would go through five stages: The first is from sloping fields to vegetation dominated by shrubs and herbs which takes about two years. The second stage is to vines and thorny shrubs (nine years). The third is to a combined stand initiation/shrub vegetation (seven years). The fourth is to open forest (ten years) and the fifth and final stage is to karst forest (nine years). In this study we combined these five successional stages into two phases. The first is from sloping fields to stand initiation/shrub which takes about 18 years and then to karst forest taking about 19 years. A recent study by Tian et al. (2011) presented the carbon density of different land use types in the karst region of Guizhou province in 2000. From this we calculated that the average carbon sequestration would be $0.19 \mathrm{t}(\mathrm{C}) \mathrm{hm}^{-2} \cdot \mathrm{a}^{-1}$ during the first 18 years in the succession towards shrubbery land and $1.20 \mathrm{t}(\mathrm{C}) \mathrm{hm}^{-2} \cdot \mathrm{a}^{-1}$ during the next 19 years of succession into karst forest.

\subsection{Changes of Ecosystem Services after Stopping Sloping Cultivating}

Using Equation (1) and the equivalent values of China's terrestrial ecosystem (Table 1) we calculated the unit economic value and total economic value of ecosystem services provided by six kinds of ecosystems (Table 2) in Guizhou province for the year 2005 and found it to be 796 yuan $\cdot \mathrm{hm}^{-2} \cdot \mathrm{a}^{-1}$. Unused land, urban settlement, mining, transportation and water conservancy facilities were all included in the desert ecosystem in this study, which gave the lowest economic value among the six ecosystems. We found that the wetland ecosystem had the largest economic value per $\mathrm{hm}^{2}$, followed by water body, forest, grassland, farmland, and desert (Table 2). Forest would provide 2.57 times more ecosystem services than farmland.

\subsection{Opportunity Cost of Farmers When Stopping Sloping Cultivating}

In karst-rich counties of China, the cultivated land per capita is only $0.06 \mathrm{hm}^{2}$. Furthermore, sloping cultivated land accounts for $70 \%$ of the total cultivated land, of which $20 \%$ has an inclination of more than 25 (Huang et al., 2008) which equals an area of $973,500 \mathrm{hm}^{2}$. At least $33,000 \mathrm{hm}^{2} \cdot \mathrm{a}^{-1}$ have been changed to forest land since the SLCP programme started in 2000 (Luo, 2000). The compensation is in accordance with the standards of Yangtze River Basin which is $2250 \mathrm{~kg} \cdot \mathrm{hm}^{-2} \cdot \mathrm{a}^{-1}$ of the local crops (Zhao \& Wang, 2010). Farmers were compensated with 1.4 yuan $\cdot \mathrm{kg}^{-1}$. 
Table 2. Economic value of services function of six ecosystems in the Guizhou province.

\begin{tabular}{cccc}
\hline Ecosystems & Unit economic value $\left(\right.$ yuan $\left.(\mathrm{RMB}) \mathrm{hm}^{-2} \cdot \mathrm{a}^{-1}\right)$ & Area $\left(\times 10^{4} \mathrm{hm}^{2}\right)$ & Economic value $\left(\times 10^{8}\right.$ yuan $\left.(\mathrm{RMB})\right)$ \\
\hline Forest & $15,649.36$ & 804.12 & 1215.71 \\
Grassland & 5763.04 & 160.64 & 92.58 \\
Farmland & 5500.36 & 450.50 & 247.79 \\
Wetland & $49,917.16$ & 0.82 & 4.09 \\
Water body & $36,616.00$ & 10.67 & 39.07 \\
Desert & 334.32 & 334.78 & 11.19 \\
Total & & 1761.53 & 1610.43 \\
\hline
\end{tabular}

More than $50 \%$ of the cultivated land has medium or low productivity. The average yield of grain is only 2 $265 \mathrm{~kg} \cdot \mathrm{hm}^{-2}$, much lower than the national average $\left(9285 \mathrm{~kg} \cdot \mathrm{hm}^{-2}\right)$ (Huang et al., 2008). The market price of maize was 2.46 yuan $\mathrm{kg}^{-1}$, resulting in the farmers' average income and opportunity cost of stopping sloping farming to be just below 47 yuan per year (Table 3). The annual income per capita would decrease with around 20 yuan per year.

\section{Discussion}

Yang et al. (1994) pointed out that low biodiversity, simple structure, and poor anti-interference ability are the main characteristics of karst forests that make them different from other subtropical forests. Average biomass of Maolan karst forest—a typical karst forest located in south Guizhou—was around $149 \mathrm{t} \cdot \mathrm{hm}^{-2}$. This was far less than the biomass of non-karst forest and even lower than that of the deserts or northern taiga $\left(150 \mathrm{t} \cdot \mathrm{hm}^{-2}\right.$ ) (Yang \& Chen, 1991). Su and Zhu (2000) compared NPP of several typical tree species, shrubs and grasslands in Puding county (which is a classic karst region located in the middle of Guizhou) and found it to be $57.5 \%$, 28\% and 56.6\%, respectively, of the Chinese national average. Wang et al. (2007) studied NPP of Guizhou's vegetation, both in karst and non-karst areas and showed that NPP of karst vegetation was $4.07 \mathrm{t}(\mathrm{C}) \mathrm{hm}^{-2} \cdot \mathrm{a}^{-1}$ in 2001 while NPP of non-karst vegetation was more than $13 \%$ higher, which tells us that both karst and non-karst areas in Guizhou have lower NPP than other parts at the same latitude in China. Li and Ren (2004) compared their results of biomass and NPP calculations of subtropical evergreen broadleaf forest in China with four other studies. They found it to be between 6.27 and $8.40 \mathrm{t}$ (C) hm $\mathrm{hm}^{-2} \cdot \mathrm{a}^{-1}$ and higher than the NPP during succession processes of the karst forest. Analysing NPP using land use data, it becomes obvious that NPP of agricultural land is lower than that of forest land. From Chen et al. (2002) we could calculate NPP of different vegetation types and different land use in China in the year 1990 (Figure 3). Average NPP of forest land was $9.7 \mathrm{t} \cdot(\mathrm{C}) \cdot \mathrm{hm}^{-2} \cdot \mathrm{a}^{-1}$, agricultural land and shrub land slightly lower, whereas that of grassland was the lowest.

Although these studies adopted different methods, all show that biomass and NPP in karst regions are less than those in non-karst regions in the same climate zone. This is due to the integrated ecological conditions of the area. Yang et al. (1994) showed clearly that the main reason of the relatively low forest biomass and NPP is due to soil conditions rather than climatic conditions. Furthermore, Yan et al. (2007) pointed out that parts of the cropland areas in the Yunnan-Guizhou Plateau have suffered from a reduction of agricultural productivity from 1981 to 2000. They expressed the meaning that spatial heterogeneity of agricultural productivity was predominantly controlled by the topographic conditions at a decadal scale. This could also explain why the average grain yield in Guizhou is much lower than the national average. At the same time it also confirms the fact that karst ecosystems have low biological productivity. That means for producing the same quality and quantity of agricultural products farmers in the karst region have to pay more both in terms of labour and time. Even after they get the products their trouble is not over. The extremely fragile karst ecosystem is damaged by this inappropriate land use and the result is serious soil erosion on the sloping fields, water pollution in groundwater and downstream, and finally, irreversible ecological degradation. Therefore, could we say that the karst mountain regions are not a place to provide food for people? In fact we know that karst mountain regions are not grain-producing areas in China, but the Chinese people traditionally want to grow their own crop and rarely consider any other trade, thus they become farmers also in less suitable areas. Therefore we need to find another way to make sus- 
Table 3. Average annual income and opportunity cost per capita before and after the SLCP started in Guizhou.

\begin{tabular}{|c|c|c|c|c|c|c|c|c|c|}
\hline & $\begin{array}{l}\text { Average } \\
\text { yield of } \\
\text { grain } \\
\left(\mathrm{kg} \cdot \mathrm{hm}^{-2}\right)\end{array}$ & $\begin{array}{c}\text { Compensation } \\
\text { standards } \\
\left(\mathrm{kg} \cdot \mathrm{hm}^{-2}\right)\end{array}$ & $\begin{array}{l}\text { Market } \\
\text { price } \\
\text { of grain } \\
\text { (yuan } \cdot \mathrm{kg}^{-1} \text { ) }\end{array}$ & $\begin{array}{c}\text { Area of per } \\
\text { capita to get } \\
\text { compensation } \\
\left(\mathrm{hm}^{2}\right)\end{array}$ & 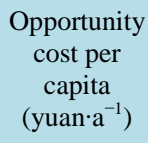 & $\begin{array}{l}\text { Compensation } \\
\text { from SLCP } \\
\text { per capita } \\
\left(\mathrm{kg} \cdot \mathrm{a}^{-1}\right)\end{array}$ & $\begin{array}{l}\text { Average } \\
\text { grain price } \\
\text { of SLCP } \\
\left(\text { yuan } \mathrm{kg}^{-1} \text { ) }\right.\end{array}$ & 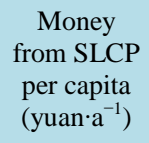 & 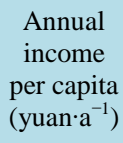 \\
\hline No SLCP & 2265 & - & 2.46 & 0.0084 & 0 & 0 & - & 0 & 334.31 \\
\hline SLCP & 2265 & 2250 & 2.46 & 0.0084 & 46.80 & 18.9 & 1.4 & 26.46 & 313.97 \\
\hline
\end{tabular}

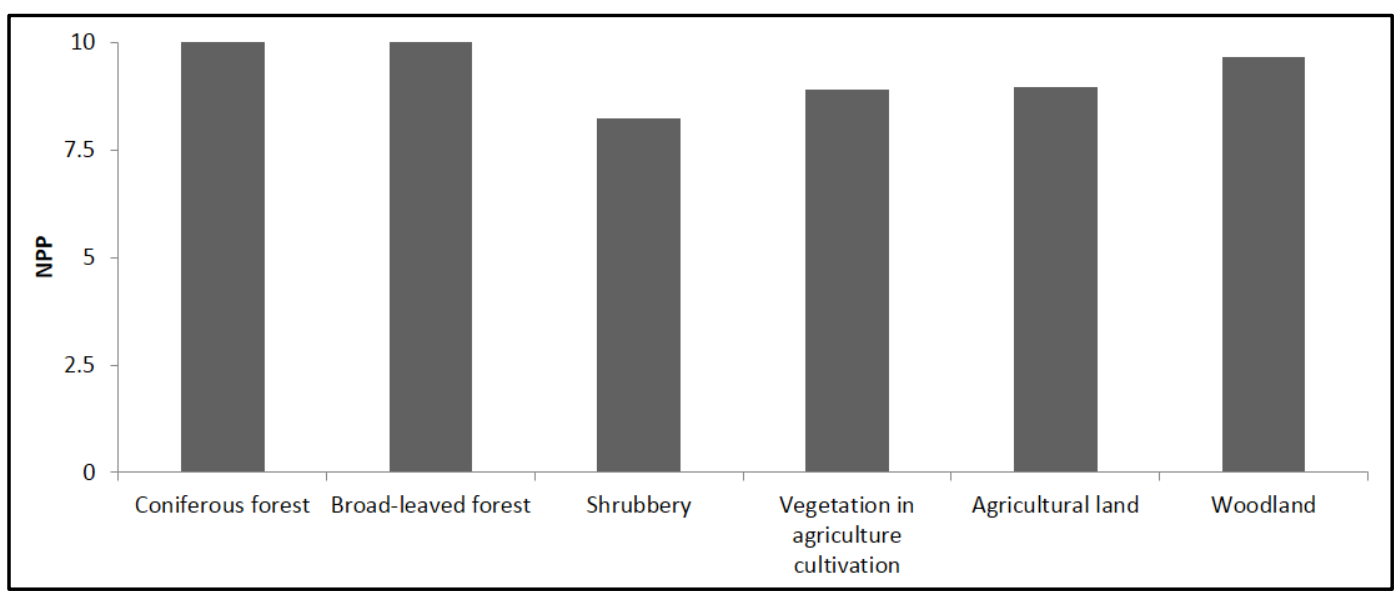

Figure 3. NPP $\left(\mathrm{tCh} \cdot \mathrm{m}^{-2} \cdot \mathrm{a}^{-1}\right)$ in 1990 of different vegetation or land use types (adapted from Chen et al., 2002).

tainable development for both nature and society in the karst region. This means that the alternatives to the present land-use must be attractive to the farmers, not least in terms of money. We believe our EC model fulfil that requirement.

According to our study, if all sloping land is changed to forest, the economic value of the ecosystem services would increase 2.57 times. These ecosystem services would not only benefit the local people but also those living downstream along the Pearl and Yangtze rivers. The services of ecological systems and the natural capital stocks that produce them are critical to the functioning of the earth's life support system (Costanza et al., 1997). Costanza et al. also stressed that it is not particularly meaningful to ask how large the total value of the natural capital is to human welfare. The question is instead how changes in the quantity or quality of various types of natural capital and ecosystem services may impact human welfare. The Chinese Central Government has been trying to compensate the loss of income to farmers for conservation of the environment through the implementation of projects such as NFPP and SLCP (Wan et al., 2005). According to SLCP's compensation standard, if one farmer gives up all his fields (the average is $0.06 \mathrm{hm}^{2}$ ) then he would get $189 \mathrm{yuan} \cdot \mathrm{a}^{-1}$. At the same time there are some local government's grants for them. Everyone in the karst mountain regions of Guizhou would get 1000 yuan $\mathrm{a}^{-1}$ for developing planting or breeding from 2014 to 2016. And at the end of 2016, 6 million of the poorest people in Guizhou will each get the compensation of 1000 yuan from the local government. Nevertheless, it is difficult for them to get enough food and clothing. Obviously farmers need additional compensation to escape poverty, and only then could they gain the possibility to achieve sustainable development. In fact some countries have been focusing on ecological compensation as a method to solve the environmental problem or to preserve the ecosystems that provide the services (Pagiola et al., 2007; Engel et al., 2008; Wunscher et al., 2008). Zheng and Kou (2011) stressed that EC in River Basin is one of the important means to settle water resource conflicts between upstream and downstream villages, and they established an EC mode scheme in the Beijing water source areas. Li and Sun (2010) put forward that EC has an important function in coordinating trans-regional resources and reallocating benefits. We believe that EC in the karst region could also achieve this function.

The purpose of EC is not only for today but also for the future. That means EC not only provides money for improving the present living standard, but also a changed lifestyle and a build-up of sustainable industries, so we build a EC mechanism for 20 years to achieve sustainable development during which the proportion of EC will 
change (Figure 4). During these 20 years we assume that the new industry (e.g., planting economic tree species, developing bee-keeping, learning handicraft, housing repair work, rural tourism) will have developed. Thus, after 20 years the villagers will no longer be dependent on EC.

During the 20 years, funding of EC would come from financial institutions at all levels of government, downstream enterprises of Pearl River, and eco-tax (Figure 5). However, all the funding should be collected by the government and supervised by the third part. The main obligations of the third part are to monitor the changes of environment, economy and society, track the process of the EC program, evaluate the execution of the contract between part A (encompassing the financial institutions at all levels of government, downstream enterprises of Pearl River and eco-tax) and part B (encompassing the local people in the karst region) and to provide suggestions at any time.

If our EC scheme is implemented, we believe that the inhabitants of Bangui town could get ecological compensation funding for four reasons. The first reason is that they provide ecological services values. The second is the opportunity cost of the locals to protect the environment. The third is poverty because of geographic reasons (Jalan \& Ravallion, 2002), such as severe undulating surface and lack of water and soil resources.

The last reason is that the development of karst areas is seriously lagging behind for historical reasons, and reducing regional differences is one of the Chinese government's objectives. Past EC projects did not have the desired effects as the projects were implemented in wide-ranging areas, e.g., the whole of west China or the whole area around the southern parts of the Yangtze River. In addition, the compensation to the farmers was too small and it was impossible to mobilize any enthusiasm from them (Zhao \& Wang, 2010). The farmers definitely need a special EC to improve their living standards while achieving ecosystem restoration. Sachs and Reid (2006) stressed that environmental goals cannot be attained without also addressing poverty; similarly, addressing poverty is essential for improving the environment; both need additional resources, particularly in developing nations.

In our EC scheme for Bangui town, we determined the compensation for 5-year periods (Table 4). Per capita income of urban residents in Guanling County is a benchmark. For example, if per capita income is 800 yuan in 2014, the compensation would be 640 yuan/month from 2014 to 2019. In this study, we also assumed that in 2019, 2024 and 2029 per capita monthly income is 1200, 1500 and 2000 yuan, respectively, giving 1 person's compensation to be 720 (60\% of 1200), 600 (40\% of 1500$)$ and 400 (20\% of 2000$)$ yuan/month, respectively. The level of infrastructure investments in the $1^{\text {st }}-5^{\text {th }}$ year, $6^{\text {th }}-10^{\text {th }}$ year, $11^{\text {th }}-15^{\text {th }}$ year, and the $16^{\text {th }}-20^{\text {th }}$ year were $20 \%, 15 \%, 10 \%$ and $5 \%$, respectively, of the individual compensation, assuming a family of five. Therefore, our total EC scheme includes compensation for family and infrastructure investment. $10 \%$ of individual compensation will be provided to develop industry (such as planting economic trees, developing bee-keeping and rural tourism) and another $10 \%$ to be used for improving the environment (such as household water treatment, waste disposal and housing repairs), both would be managed by the third-part. According to this model,

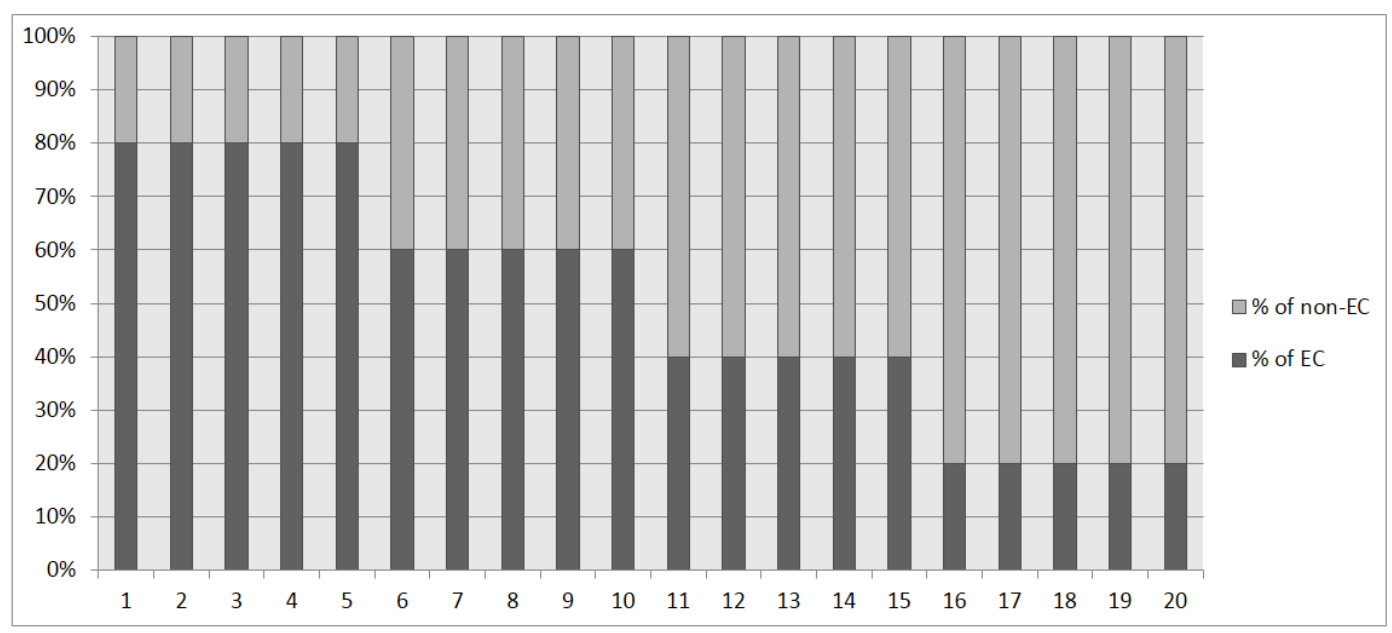

Figure 4. Proportion (\%) of ecological compensation (EC) change during 20 years. As the farmers increasingly use alternative income sources (e.g., planting economic tree species, bee-keeping, handicraft, rural tourism, housing repairs) the dependence on EC funding will decrease accordingly. 
Table 4. An Ecological Compensation model case study in Bangui village (unit is in $10^{4}$ yuan).

\begin{tabular}{|c|c|c|c|c|c|}
\hline Years & $1^{\text {st }}$ to $5^{\text {th }}$ & $6^{\text {th }}$ to $10^{\text {th }}$ & $11^{\text {th }}$ to $15^{\text {th }}$ & $16^{\text {th }}$ to $20^{\text {th }}$ & $1^{\text {st }}$ to $20^{\text {th }}$ \\
\hline One month EC for 5 persons family & 0.32 & 0.36 & 0.30 & 0.20 & \\
\hline $10 \%$ family EC for improving the environment & 0.032 & 0.036 & 0.030 & 0.020 & \\
\hline $10 \%$ family EC for developing industry & 0.032 & 0.036 & 0.030 & 0.020 & \\
\hline The total EC for 3800 families & 72,960 & 82,080 & 68,400 & 45,600 & 269,040 \\
\hline EC funds for infrastructure development & 14,592 & 12,312 & 6840 & 2280 & 36,024 \\
\hline Total & 87,552 & 94,392 & 75,240 & 47,880 & 305,064 \\
\hline
\end{tabular}

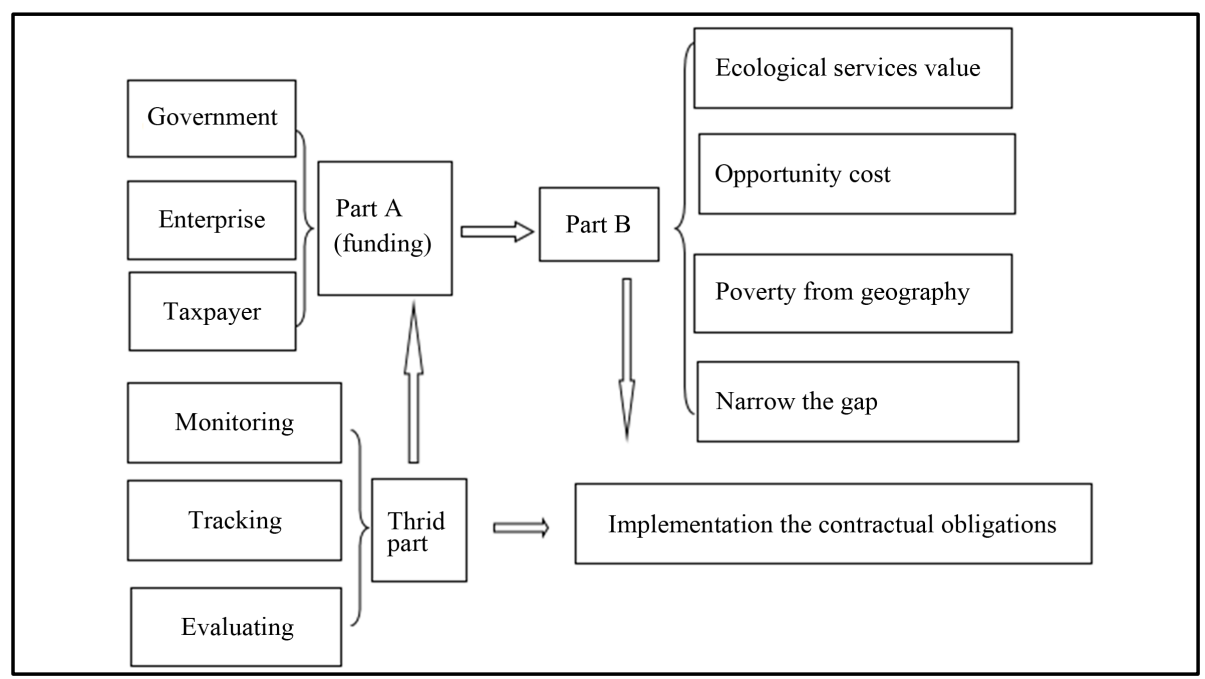

Figure 5. Ecological compensation framework map for karst regions.

the total EC for Bangui would be 305,064 $\times 10^{4}$ yuan during the 20 years. Each person will receive 141,600 yuan EC funding and enjoy public facilities from 36,024 $\times 10^{4}$ yuan investment. The public facilities include, e.g., education, health care, water, sanitation, transportation, entertainment. This compensation is not offset with other policies, so this EC project would in fact speed up the development. After 20 years, the infrastructure would be completed and the industry will bring them more and more benefits.

Our karst region EC scheme not only takes into account the ecosystem services and opportunity costs, but also focuses on long-term sustainable development for karst areas. However, to succeed with this the third part of this EC scheme need to pay more attention to the process, to ensure sufficient basis to do any of the decision-making. Yan et al. (2011, 2012) estimated carbon uptake from chemical weathering of all karsts in China to be about $12 \mathrm{Tg} \cdot \mathrm{C} \cdot \mathrm{a}^{-1}$, or about $57 \%$ of the rate of net carbon accumulated in the forest biomass from 1981 to 1998 in China. They, therefore, recommend the inclusion of carbon uptake from chemical weathering in the regional carbon budget of China. Chemical weathering in karst regions is a huge contribution to the carbon balance, the impact of human activities in this process is our next research goal. Another important factor to consider is to properly continue the forest inventory scheme (Lin et al., 2013).

\section{Implications for Practice}

On the basis of field measurements, literature study and analysis, we find that it has become increasingly necessary to establish a particular Ecological Compensation scheme for karst areas, to save the rapidly degrading natural forest ecosystem and reduce poverty. There is no other way to make the karst areas achieve a sustainable development. Due to the particularity of the karst region of southwest China, we have built an EC scheme that is not restricted by opportunity costs or the value of ecosystem services or other factors. It is more suited to local conditions, and stresses ease of operation and promotion. 


\section{Acknowledgements}

This publication has been produced during Dr Chuanyan Zhou's scholarship period at Uppsala University, thanks to a Swedish Institute scholarship. We also thank Jingang Tang, Shiqin Luo, Yifan Wang and Weiquan Zhao for their assistance. This research was supported by Governor fund of Guizhou province (200956), International scientific and technological cooperation project of Guizhou province (20127032), Guizhou social development project (SY20103015), and National twelfth five-year science and technology project

(2011BAC09B01).

\section{References}

Cai, Y. L. (2006). Eco-Tourism. An Approach to Escaping from the "Poverty Trap” in Karst Mountains of Southwestern China. China Population, Resources and Environment, 16, 113-116.

Cao, S. X., Zhong, B. L., Hui, Y., Zeng, H. S., \& Zeng, J. H. (2009). Development and Testing of a Sustainable Environmental Restoration Policy on Eradicating the Poverty Trap in China's Changting County. Proceedings of the National Academy of Sciences, 106, 10712-10716. http://dx.doi.org/10.1073/pnas.0900197106

Chen, L. J., Liu, G. H., \& Guo, L. H. (2002). Estimating Net Primary Productivity of Terrestrial Vegetation in China Using Remote Sensing. Journal of Remote Sensing, 6, 129-135.

Costanza, R., Arge, R. Groot,R., Farber, S., Grasso, M., Hannon, B., Limburg, K., Naeem, S., et al. (1997). The Value of the World's Ecosystem Services and Natural Capital. Nature, 387, 253-260. http://dx.doi.org/10.1038/387253a0

Engel, S., Pagiola, S., \& Wunder, S. (2008). Designing Payments for Environmental Services in Theory and Practice: An Overview of the Issues. Ecological Economics, 65, 663-674. http://dx.doi.org/10.1016/j.ecolecon.2008.03.011

Huang, Q. H., Cai, Y. L., \& Xing, X. S. (2008). Rocky Desertification, Antidesertification, and Sustainable Development in the Karst Mountain Region of Southwest China. Ambio, 37, 390-392. http://dx.doi.org/10.1579/08-S-493.1

Huang, W. L., Tu, Y. L., \& Yang, H. L. (1988). Vegetation of Guizhou. Guizhou People Press, Guiyang

Jalan, J., \& Ravallion, M. (2002). Geographic Poverty Traps? A Micro Model of Consumption Growth in Rural China. Journal of Applied Econometrics, 17, 329-346. http://dx.doi.org/10.1002/jae.645

Jashimuddin, M., \& Inoue, M. (2012). Management of Village Common Forests in the Chittagong Hill Tracts of Bangladesh: Historical Background and Current Issues in Terms of Sustainability. Open Journal of Forestry, 2, 121-137.

http://dx.doi.org/10.4236/ojf.2012.23016

Li, G. F., \& Ren, H. (2004). Biomass and Net Primary Productivity of the Forests in Different Climatic Zones of China. Tropical Geography, 24, 306-311. http://dx.doi.org/10.1016/j.jtrangeo.2012.03.008

Li, P. X., \& Sun, W. (2010). Theoretical Reflection on Ecological Compensation from the Perspective of Economic Geography. Ecology and Environmental Sciences, 19, 1507-1512.

Lin, G., Wen, X., Zhou, C., \& She, G. (2013). Review and Progress of China’s Forest Continuous Inventory System. Open Journal of Forestry, 3, 17-22. http://dx.doi.org/10.4236/ojf.2013.31004

Luo, Z. K. (2000). Desertification Control and Ecological Environment Restoration in Guizhou Karst Regions. Guizhou Environmental Sciences and Technology, 6, 7-10.

Pagiola, S., Ramirez, E., Gobbi, J., de Haan, C., Ibrahim, M., Murgueitio, E., \& Ruiz, J. P. (2007). Paying for the Environmental Services of Silvopastoral Practices in Nicaragua. Ecological Economy, 64, 374-385. http://dx.doi.org/10.1016/j.ecolecon.2007.04.014

Peng, W. X., Wang, K. L., Song, T. Q., Zeng, F. P., \& Wang, J. R. (2008). Controlling and Restoration Models of Complex Degradation of Vulnerable Karst Ecosystem. Acta Ecologica Sinica, 28, 811-820.

Sachs, J. D., \& Reid, W. V. (2006). Investments toward Sustainable Development. Science, 312, 1002. http://dx.doi.org/10.1126/science.1124822

Sawakuchi, H. O., Ballester, M. V. R., \& Ferreira, M. E. (2013). The Role of Physical and Political Factors on the Conservation of Native Vegetation in the Brazilian Forest-Savanna Ecotone. Open Journal of Forestry, 3, 49-56. http://dx.doi.org/10.4236/ojf.2013.31008

Su, W. C., \& Zhu, W. X. (2000). The Eco-Environment Fragility in Karst Mountain Regions of Guizhou Province. Journal of Mountain Science, 18, 429-434.

Tian, X. L., Xia, J., Xia, H. B., \& Ni, J. (2011). Forest Biomass and Its Spatial Pattern in Guizhou Province. Chinese Journal of Applied Ecology, 22, 287-294.

Thiombiano, D. N. E., Lamien, N., Castro-Euler, A. M., Vinceti, B. Agundez, D., \& Boussim, I. J. (2013). Local Communities Demand for Food Tree Species and the Potentialities of Their Landscapes in Two Ecological Zones of Burkina Faso. 
Open Journal of Forestry, 3, 79-87. http://dx.doi.org/10.4236/ojf.2013.33014

Wan, J. (2003). Land Degradation and Ecological Rehabilitation in Karst Areas of Guizhou Province, Southwestern China. Advances in Earth Sciences, 18, 447-453.

Wan, J., Zhang, H. Y., Wang, J. N., Ge, C. Z., Gao, S. T., \& Rao, S. (2005). Policy Evaluation and Framework Discussion of Ecological Compensation Mechanism in China. Research of Environmental Sciences, 18, 1-8.

Wang, S. J., Liu, Q. M., \& Zhang, D. F. (2004). Karst Rocky Desertification in Southwestern China: Geomorphology, Landuse, Impact and Rehabilitation. Land Degradation and Development, 15, 115-121. http://dx.doi.org/10.1002/ldr.592

Wang, B., Yang, S. T., \& Wang, Y. J. (2007). Estimation on Net Primary Productivity of Vegetation in Karst Area of Guizhou Province. Carsologica Sinica, 26, 98-104.

Wunscher, T., Engel, S., \& Wunder, S. (2008). Spatial Targeting of Payments for Environmental Services: A Tool for Boosting Conservation Benefits. Ecological Economics, 65, 822-833. http://dx.doi.org/10.1016/j.ecolecon.2007.11.014

Xiao, Y., Xie, G. D., \& An, K. (2003). Economic Value of Ecosystem Services in Mangcuo Lake Drainage Basin. Chinese Journal of Applied Ecology, 14, 676-680.

Xie, G. D., Lu, C. X., Leng, Y. F., Zheng, D., \& Li, S. C. (2003). Ecological Assets Valuation of the Tibetan Plateau. Journal of Natural Resources, 18, 189-196.

Xie, G. D., Xiao, Y., \& Lu, C. X. (2006). Study on Ecosystem Services: Progress, Limitation and Basic Paradigm. Chinese Journal of Plant Ecology, 30, 191-199.

Yan, H. M., Liu, J. Y., \& Cao, M. K. (2007). Spatial Pattern and Topographic Control of China’s Agricultural Productivity Variability. Acta Geographica Sinica, 62, 171-180.

Yan, J. H., Li, J. M., Ye, Q., \& Li, K. (2012). Concentrations and Exports of Solutes from Surface Runoff in Houzhai Karst Basin, Southwest China. Chemical Geology, 304-305, 1-9. http://dx.doi.org/10.1016/j.chemgeo.2012.02.003

Yan, J. H, Wang, Y. P., Zhou, G. Y., Li, S. G., Yu, G. R., \& Li, K. (2011). Carbon Uptake by Karsts in the Houzhai Basin, Southwest China. Journal of Geophysical Research: Biogeosciences, 116, G0412.

Yang, H. K., \& Chen, S. Z. (1991). Study on Biomass of the Karst Community in Maolan, Guizhou Province. Acta Ecological Sinica, 11, 307-312.

Yang, H. K., Zhu, W. X., Li, P., Chen, S. Z., \& Tian, W. X. (1994). Environmental Quality Vary in Karst Regions. Guiyang: Guizhou Sciences and Technology Press.

Zhang, D. F., Ouyang, Z. Y., \& Wang, S. J. (2001). Population Resources Environment and Sustainable Development in the Karst Region of Southwest China. China Population, Resourcesand Environment, 11, 77-81.

Zhang, W., Zhang, H. Y., \& Zhang, Y. F. (2010). The Determination of Social Ecological Compensation Standard Based on "Equivalent Value of Geographical Factor Endowment”. Acta Geographica Sinica, 65, 1253-1265.

Zhao, C. W., \& Wang, S. J. (2010). Benefits and Standards of Ecological Compensation: International Experiences and Revelations for China. Geographical Research, 29, 597-606.

Zheng, H. X., \& Kou, Y. J. (2011). The Modes and Mechanisms of Ecological Compensation in Water Source Areas, Beijing, China. Energy Procedia, 13, 4300-4306. 